\title{
DO SUBMERGED PLANTS IMPROVE THE WATER QUALITY IN MINING SUBSIDENCE RESERVOIRS?
}

\author{
PIERZCHA£A, . $^{{ }^{*}}{ }^{*}$ SIERKA, E. ${ }^{2}$ \\ ${ }^{1}$ Central Mining Institute in Katowice, Department of Water Protection \\ Plac Gwarków 1, 40-166 Katowice, Poland \\ (phone: +48-32-259-2000; fax: +48-32-259-6533) \\ ${ }^{2}$ University of Silesia in Katowice, Faculty of Natural Sciences, Institute of Biology, \\ Biotechnology and Environmental Protection, Jagiellońska 28, 40-032 Katowice, Poland \\ (phone: +48-32-255-5873; fax: +48-32-200-9361) \\ *Corresponding author \\ e-mail: lpierzchala@gig.eu; phone: +48-32-254-2292; fax: +48-32-254-2452 \\ (Received 31 ${ }^{\text {st }}$ Dec 2019; accepted 22 ${ }^{\text {nd }}$ May 2020)
}

\begin{abstract}
This paper provides an analysis of the effect of submerged vegetation on the physicochemical parameters of water with particular regard to transparency in mining subsidence reservoirs (MSR). The research encompassed 8 subsidence reservoirs with a diversified structure of submerged plants in the littoral zone. It has been proven that reservoirs where submerged vegetation coverage is greater than $25 \%$ of the water surface area are characterized by significantly greater transparency of water. High water transparency is desirable due to a greater utility value of reservoirs and their biologic diversity. The results from this research indicate that supporting the development of submerged vegetation in mining subsidence reservoirs may be an effective method for improving the water quality of such reservoirs.
\end{abstract}

Keywords: submerged vegetation, mining subsidence reservoirs, water clarity, alternative stable states, physicochemical parameters

\section{Introduction}

Subsidence reservoirs, as anthropogenic water ecosystems, are generally formed as a result of underground mining activity. This type of reservoirs compared to natural reservoirs (Sierka et al., 2012), frequently characterize high concentrations of dissolved substances, primarily sulfates and chlorides, and may be subject to intensive eutrophication (Raclavská et al., 2003; Strzelec et al., 2010; Kašovská et al., 2014). The water eutrophication is leading to dominance of algae, as well as reduction or even elimination of submerged plants, and cause the deterioration of water quality in reservoirs (Irfanullah and Moss, 2004). Hasler and Jones (1949), Jeppesen et al. (1990), Gross and Sütfeld (1994), Coops and Doef (1996), Bachmann et al. (2002), Nakamura et al. (2008), Kosten et al. (2009), Li et al. (2014), Phillips et al. (2016) and Verhofstad et al. (2017) have proved in their research that submerged plants have the capability to increase the clarity of water and efficiency of pollutant removal e.g. lakes. As a starting point of investigation within this paper should be the resume of general ideas behind the alternative stable states theory for shallow lakes. The theory indicates that if submerged plants are abundant, they can greatly reduce turbidity (Scheffer et al., 1993). Is the fact that the research has been conducted for almost 30 years. The problem of maintaining the clarity of water is still valid (Wang et al., 2019), because it is closely related to the searching of effective methods to maintain good status of water ecosystems. Access to the reservoirs with clear water for citizens, especially in urban and periurban areas 
(Woźniak et al., 2018), is important factor to enhance their well-being. Furthermore, only ecosystems with good water quality deliver suitable habitats for aquatic organisms (Tokarska-Guzik and Rostański, 1996; Pierzchała et al., 2016).

One of the water quality parameters is clarity which indicates the presence or absence of suspended matter, and hence it is a reflection of the overall quality of the water. The role of macrovegetation in reservoirs formed in subsidence basins as a factor related to improving water quality is unknown. It seems that understanding the relationship between the functioning of submerged vegetation and water parameters in mining subsidence reservoirs may be the basis for their effective restoration (Hilt et al., 2006). In natural shallow reservoirs, vegetation is not the only one parameter used for the evaluation of the ecological condition of water ecosystems. Aquatic plants, particularly species with submerged leaves, compete with algae for domination in the water ecosystems.

The main aim of this paper is to answer these questions:

1 ) is submerged vegetation a factor promoting water clarity in mining subsidence reservoirs as in lake?

2) does water clarity depends from submerged vegetation percentage cover surface area of the mining subsidence reservoirs?

\section{Materials and methods}

\section{Area of research}

The research was conducted within subsidence reservoirs located in Karvina county, Czechia. The area of research is part of the Ostrava-Karvina coal basin located within the Moravian-Silesian Region in the North-Eastern part of Czechia. The region is entirely industrial in nature and its landscape has been strongly affected by coal mining activities (Macoun et al., 1965; Menčik, 1983). There are also dozens of fresh water reservoirs of various size, formed due to direct activity (storage reservoirs, fish ponds) and indirect human activity (subsidence reservoirs). The accumulation of water is geologically related to Quaternary layers, primarily Quaternary sands and clayey sands that prevail in this area (Plaček, 1984). The elevated salinity of water in subsidence reservoirs is primarily the effect of washing out substances from mine waste dumps (Molenda and Rzętała, 2001). In addition, gangue (waste material from mining) is frequently used to shape the shore of the analyzed objects. The leaching of readily soluble mineral components (primarily chlorides and sulfates) from such formations leads to the higher salinity of the water.

In order to conducted research on the effect of the aqatic vegetation on water chemistry, informed by former reaserch (Raclavská et al., 2003; Stalmachová, 2003; Pertile, 2007), 8 reservoirs of diverse salinity and trophic status were selected (Figure 1). All of the selected reservoirs had undergone spontaneous succession for at least 10 years. The hydromorphological properties of the analyzed reservoirs are presented in Table 1.

\section{Methodology}

Water samples were collected from May to October in monthly intervals in 2010. The sampling points (one par lake) were determined within the littoral zone, at a distance of over $50 \mathrm{~m}$ from the reservoir's inlet and outlet, where water movement was 
undisturbed. The water transparency were measured in situ by Secchi Disk. The depth where the Secchi Disk settles beyond visual recognition, was determined as an index of water transparency - SD (Secchi Depth). The laboratory analyses included the following physico-chemical parameters: pH, TSS (Total Suspended Solids), TDS (Total Dissolved Substances), TN (Total Nitrogen), and TP (Total Phosphorus) were conducted in accordance with appropriate standards ISO. Seasonal mean values of the parameters were used for further computational analyses.

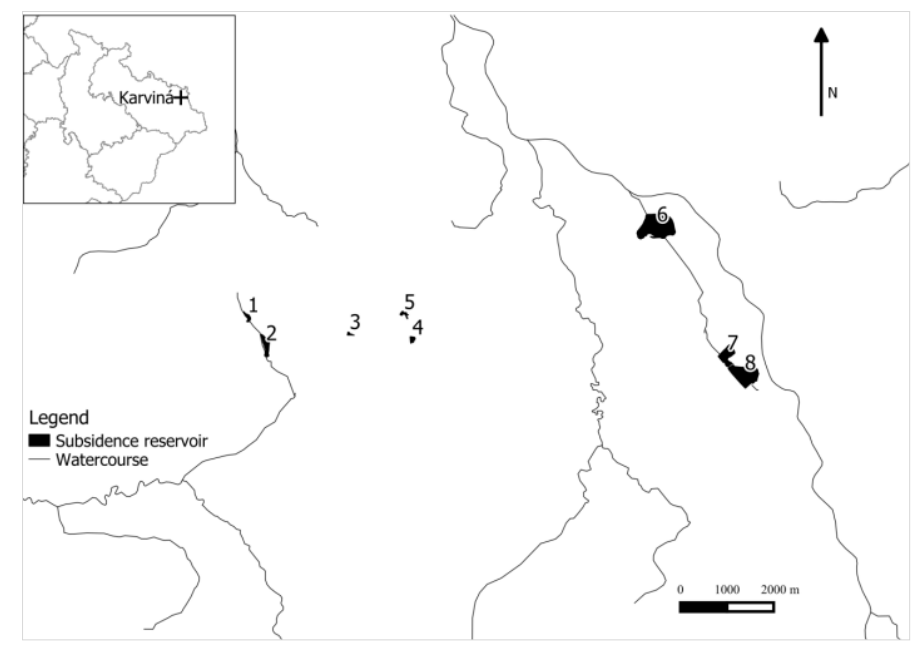

Figure 1. Location of the research subjects. 1 - Pod lesem, 2 - Bartošůvka, 3 - František, 4 Barbora, 5 - U cesty, 6 - Darkovské moře, 7 -Velký Myškovec, 8 - Mlýnské rybníky against the background of the hydrographic network

Table 1. Hydromorphological properties of the analysed reservoirs

\begin{tabular}{c|c|c|c|c|c|c}
\hline $\begin{array}{c}\text { Subject } \\
\text { No. }\end{array}$ & $\begin{array}{c}\text { Name of the } \\
\text { reservoir }\end{array}$ & $\begin{array}{c}\text { Depth } \\
{[\mathbf{m}]}\end{array}$ & Area [ha] & $\begin{array}{c}\text { Circumference of } \\
\text { the reservoir [m] }\end{array}$ & $\begin{array}{c}\text { Shore with forest } \\
\text { covered area [\%] }\end{array}$ & $\begin{array}{c}\text { Flow-through } \\
\text { reservoir }\end{array}$ \\
\hline 1 & Pod lesem & 2.5 & 1.34 & 701 & 85.8 & Yes \\
2 & Bartošůkka & 8.5 & 3.95 & 1070 & 0 & Yes \\
3 & František & 5 & 0.57 & 386 & 29.2 & No \\
4 & Barbora & 4.5 & 1.24 & 740 & 51.3 & No \\
5 & U cesty & 4.5 & 0.79 & 368 & 45.3 & No \\
6 & Darkovské moře & 25 & 34.9 & 2311 & 0 & Yes \\
7 & Velký Myškovec & 3.5 & 6.56 & 1106 & 74.1 & Yes \\
8 & Mlýnské rybník & 3 & 17.33 & 2288 & 17.8 & Yes \\
\hline
\end{tabular}

Vegetation research was conducted in August 2010, when there was a stable water level according to the methodology by Grulich and Vydrová (2006). Each reservoir, depending on its surface, was divided into 6-10 transects perpendicular to the shoreline. Transects were further divided into zones with regard to their depth: 0-1 m, 1-2 m, 2-3 m, >4 m (Schaumburg et al., 2004). In each zone there were 2 research plots of an area of $1 \mathrm{~m}^{2}$. The composition of the aquatic vegetation, in terms of species and coverage of each, species was determined as a percentage: $0,1,10,20,30 \ldots 100 \%$. To characterise the spatial structure of macrophytes of each reservoir the average percentage of vegetation coverage for individual species was calculated and this value was used for further analysis. 
The different aquatic vegetation were classified according to their ecological groups: elodeids -classified submerged macrophytes and nymphaeids - plants rooted in the bottom with leaves floating on the water surface.

The normality data of distribution within particular groups was confirmed using the Shapiro-Wilk test. The parametric T-test (Statistica 12.0) was employed to determine the significance of differences among particular groups with regard to the values of physico-chemical and hydromorphological indicators. The relationship between the aquatic vegetation characteristics and physico-chemical parameters of the water samples were analysed using Pearson's linear correlation coefficient.

In order to determine the habitat conditions that differentiate the type of aquatic and coastal vegetation, a linear model of ordination analysis, PCA (Principal Component Analysis) was applied. The PCA was used to: 1) identify the main differentiation patterns of aquatic vegetation and 2) determine the relationship between the differentiation of vegetation and the analyzed environmental factors. RDA (Redundancy Analysis) was employed to determine to what extent coverage of elodeids and nymphaeids affect the diversity of basic water quality parameters (SD, TN, TP, TSS). The Monte Carlo permutation test (499 permutations) was used to determine the significance of explanatory variables in the RDA model. The analysis was conducted using the CANOCO package. Prior to analysis all environmental data ver $\log (x+1)$ transformed (Šmilauer and Lepš, 2014).

In order to define the major relationships between the percent cover type of aquatic vegetation and hydromorphological and physico-chemical water parameters, a parametric test of Pearson's correlation coefficient was conducted (Statistica 12.0). Parameters that showed significant statistical correlation $(p<0.05)$ were included in the ordination analysis. Due to the length of the gradient obtained in the preliminary Canonical Correspondence Analysis (CCA) (gradient length <3), the linear model of ordination analysis (PCA and RDA) was used (Lepš and Šmilauer, 2000). Ordination analysis were conducted in CANOCO 4.1.

\section{Results}

The main species, in the reservoirs sampled forming submerged vegetation communities are Ceratphyllum demersum, Myriophyllum spicatum, and Najas marina (Table 2). With regard to the type of vegetation, submerged vegetation in reservoirs 6 , 4,3 and 5 plant cover a was greater than $25 \%$ of the water surface area.

The analyzed reservoirs were divided into two groups with regard to the average percentage cover of submerged vegetation. The first group encompassed reservoirs where elodeids cover was at least $25 \%$ (Group I - site 6, 4, 3, 5), while the second group included reservoirs where the submerged vegetation cover less than $25 \%$ of the water surface area (Group II - site 7, 8, 1, 2). The transparency of water in Group I reservoirs exceeded $1.8 \mathrm{~m}$ and this was a statistically significant difference when compared to reservoirs where submerged vegetation was scarced. Significant differences between the analyzed groups of reservoirs were also found in the values of $\mathrm{pH}$, salinity (TDS) and the concentration of suspended solids. The mean concentration of total phosphorus in the group of reservoirs abundant in vegetation was within the range $0.011-0.06$, while in the other group it was within the range $0.01-0.03$. Moreover, no differences in nitrogen concentration were found between these groups (Table 3). No statistically 
significant differences in the morphological parameters presented in table 1 were found between the analyzed groups of reservoirs.

Table 2. Diversity of aquatic vegetation in particular reservoirs

\begin{tabular}{c|c|c|c|c|c|c|c|c|c}
\hline \multirow{2}{*}{ Number of the reservoir } & $\mathbf{6}$ & $\mathbf{4}$ & $\mathbf{3}$ & $\mathbf{5}$ & $\mathbf{7}$ & $\mathbf{8}$ & $\mathbf{2}$ & $\mathbf{1}$ \\
\cline { 2 - 8 } elodeids & \multicolumn{7}{|c|}{ Average cover [\%] } \\
\hline Ceratophyllum demersum (Cer_dem) & 57.75 & 38 & 29.17 & 28.5 & 5.76 & 1.56 & 0 & 0 \\
Elodea canadensis (Elo_can) & 0.25 & 38 & 28.33 & 4 & 0.20 & 0 & 0 & 0 \\
Lemna minor(Lem_min) & 0 & 0 & 0 & 0 & 0.10 & 0 & 0 & 0 \\
Myriophyllum spicatum (Myr_spi) & 0.75 & 0 & 0.833 & 24.5 & 0 & 0 & 0 & 0 \\
Najas marina (Naj_mar) & 28.5 & 0 & 0 & 0 & 2.93 & 1.56 & 0 & 0 \\
Najas minor(Naj_min) & 12.5 & 0 & 0 & 0 & 0 & 0 & 0 & 0 \\
Potamogeton crispus (Pot_cri) & 0.625 & 0 & 0 & 0 & 0.61 & 0 & 0 & 0 \\
Potamogeton nodosus (Pot_nod) & 2.625 & 0 & 0 & 0 & 0.30 & 0 & 0 & 0 \\
Potamogeton obtusifolius (Pot_obt) & 0.125 & 0 & 0 & 0 & 0 & 0 & 0 & 0 \\
Potamogeton pectinatus (Pot_pec) & 0.25 & 0 & 0 & 0 & 0 & 0 & 0 & 0 \\
Potamogeton lucens (Pot_luc) & 0 & 0 & 0 & 0 & 1.62 & 0 & 0 & 0 \\
Ranunculus aquatilis (Ran_aqu) & 1.125 & 0 & 0 & 0 & 0 & 0 & 0 & 0 \\
Utricularia vulgaris (Utr_vul) & 6.875 & 0 & 0 & 0 & 0 & 0 & 0 & 0 \\
\hline nymphaeids & 1.5 & 6.833 & 1.667 & 1.5 & 0.808 & 1.778 & 0 & 0 \\
\hline Nymphea alba (Nym_alb) & 0 & 0 & 0 & 0 & 0.808 & 0 & 0 & 0 \\
Polygonum amphibium(Pol_amp) & 0.375 & 2 & 0 & 1.5 & 0 & 1.778 & 0 & 0 \\
\hline
\end{tabular}

Table 3. Physico-chemical water parameters of the analyzed reservoirs

\begin{tabular}{|c|c|c|c|c|c|c|c|}
\hline Groups & $\begin{array}{c}\text { Reservoir } \\
\text { No. }\end{array}$ & $\begin{array}{c}\text { SD } \\
{[\mathbf{m}]^{*}} \\
\text { avd } \pm \mathrm{sd}\end{array}$ & $\begin{array}{c}\mathbf{p H}^{\mathbf{0}} \\
\operatorname{avd} \pm \mathrm{sd}\end{array}$ & $\begin{array}{c}\mathbf{T P} \\
{\left[\mathbf{m g} \cdot \mathbf{l}^{-1}\right]} \\
\text { avd } \pm \text { sd }\end{array}$ & $\begin{array}{c}\mathbf{T N} \\
{\left[\mathbf{m g}^{-\mathbf{1}}\right]} \\
\text { avd } \pm \mathrm{sd}\end{array}$ & $\begin{array}{c}\text { TDS } \\
{\left[\mathbf{m g} \cdot \mathbf{l}^{-1}\right]^{*}} \\
\text { avd } \pm \mathrm{sd}\end{array}$ & $\begin{array}{c}\text { TSS } \\
{\left[\mathrm{mg} \mathrm{l}^{-1}\right]^{*}} \\
\text { avd } \pm \mathrm{sd}\end{array}$ \\
\hline Group I & 6 & $2.30 \pm 0.50$ & $8.00 \pm 0.26$ & $0.013 \pm 0.01$ & $0.69 \pm 0.36$ & $727.5 \pm 55.7$ & $6.90 \pm 5.33$ \\
\hline (coverage of & 4 & $2.20 \pm 0.15$ & $7.80 \pm 0.10$ & $0.011 \pm 0.01$ & $0.48 \pm 0.20$ & $1701.3 \pm 312.82$ & $3.10 \pm 1.31$ \\
\hline submerged & 3 & $2.00 \pm 0.12$ & $8.00 \pm 0.13$ & $0.044 \pm 0.04$ & $1.18 \pm 0.18$ & $731.2 \pm 52.53$ & $3.60 \pm 2.96$ \\
\hline $\begin{array}{l}\text { vegetation } \\
\geq 25 \% \text { ) }\end{array}$ & 5 & $1.80 \pm 0.16$ & 8.0 & $0.06 \pm$ & $0.77 \pm 0.19$ & $1067.8 \pm 19.63$ & $5.70 \pm 2.50$ \\
\hline Group II & 7 & $0.70 \pm 0.24$ & $8.00 \pm 0.36$ & $0.03 \pm 0.01$ & $0.88 \pm 0.26$ & $431.6 \pm 26.69$ & $18.4 \pm 11.04$ \\
\hline (coverage of & 8 & $1.00 \pm 0.30$ & $8.00 \pm 0.18$ & $0.02 \pm 0.01$ & $1.10 \pm 0.25$ & $383.3 \pm 39.36$ & $9.30 \pm 3.84$ \\
\hline submerged & 2 & $0.70 \pm 0.06$ & $7.90 \pm 0.16$ & $0.01 \pm 0.01$ & $1.15 \pm 0.31$ & $684.0 \pm 65.14$ & $7.50 \pm 4.43$ \\
\hline $\begin{array}{l}\text { vegetation } \\
<25 \% \text { ) }\end{array}$ & 1 & $0.60 \pm 0.20$ & $7.70 \pm 0.09$ & $0.02 \pm 0.01$ & $1.49 \pm 0.33$ & $236.6 \pm 31.08$ & $21.9 \pm 19.9$ \\
\hline
\end{tabular}

Statistically significant differences between the groups $\mathrm{p} \leq 0.05$ are marked with *

The analysis of linear correlation between physico-chemical parameters of water and the type of vegetation showed the following significant: positive correlations: between water transparency (SD) and the average percentage cover of submerged vegetation (ELO) (0.95); the maximal depth of submerged vegetation (dep_lim) and water transparency (SD) (0.96); the number of species (Num_spe) and the depth (depth;0.76) and area of the reservoir (area; 0.74); between salinity (TDS) (0.7) and water transparency (SD). The negative correlation was indicated $(-0.76)$ between water transparency (SD) and total suspended solids (TSS) (Table 4).

The PCA analysis showed that the analyzed physico-chemical parameters accounted by $96.97 \%$ of the variation of vegetation. The first ordination axis (axis I) of the PCA model accounts for $52.47 \%$ of the total variation of vegetation and it has the strongest positive correlation with water of total nitrogen (TN) (0.74) and the concentration of suspended solids $(-0.68)$ (TSS). This axis has the strongest negative correlation with 
transparency (0.97) (SD) and salinity (-0.69) (TDS). This axis, therefore, determines the gradient of the strongest positive correlation with the average percentage cover of submerged vegetation (ELO) The other axis (axis II) accounts for $28.48 \%$ of the total variation of vegetation and has the positive correlation with depth (0.78), area of the reservoir (0.89) (Figure 2). Many of submerged vegetation species has the strongest positive correlation with this axis (Table 5).

Table 4. The linear correlation coefficients between seasonal mean values of physicochemical parameters of water and the type of vegetation

\begin{tabular}{c|c|c|c|c|c|c|c|c}
\hline & $\begin{array}{c}\text { SD } \\
{[\mathbf{m}]}\end{array}$ & $\mathbf{p H}$ & $\mathbf{T P}$ & $\mathbf{T N}$ & $\mathbf{T S S}$ & TDS & $\begin{array}{c}\text { Depth } \\
{[\mathbf{m}]}\end{array}$ & $\begin{array}{c}\text { Area } \\
{[\mathbf{h a}]}\end{array}$ \\
\hline Cer_dem & 0.69 & -0.16 & -0.04 & -0.44 & -0.61 & $\mathbf{0 . 7 6}$ & -0.09 & -0.30 \\
Lem_min & 0.54 & -0.34 & -0.22 & -0.51 & -0.49 & $\mathbf{0 . 8 2}$ & -0.18 & -0.32 \\
Myr_spi & 0.24 & 0.28 & $\mathbf{0 . 8 1}$ & -0.25 & -0.24 & 0.28 & -0.11 & -0.24 \\
ELO & $\mathbf{0 . 9 5}$ & 0.25 & 0.01 & -0.70 & -0.61 & 0.60 & 0.69 & 0.45 \\
NYM & 0.63 & -0.18 & -0.19 & $\mathbf{- 0 . 7 2 8}$ & -0.54 & $\mathbf{0 . 8 6}$ & -0.07 & -0.10 \\
num_spec & 0.52 & 0.53 & -0.03 & -0.59 & -0.12 & 0.08 & $\mathbf{0 . 7 6}$ & $\mathbf{0 . 7 4}$ \\
dep_lim & 0.96 & 0.33 & 0.12 & $\mathbf{- 0 . 7 5}$ & -0.63 & 0.63 & 0.59 & 0.38 \\
SD[m] & 1.00 & 0.26 & 0.12 & -0.68 & $\mathbf{- 0 . 7 7}$ & $\mathbf{0 . 7 1}$ & 0.47 & 0.27 \\
TP & 0.12 & 0.42 & 1.00 & 0.03 & -0.09 & 0.01 & -0.31 & -0.40 \\
TN & -0.68 & -0.29 & 0.03 & 1.00 & 0.55 & $\mathbf{- 0 . 7 9}$ & -0.23 & -0.23 \\
TSS & -0.77 & -0.39 & -0.09 & 0.55 & 1.00 & $\mathbf{- 0 . 7 2}$ & -0.03 & -0.01 \\
TDS & $\mathbf{0 . 7 1}$ & -0.09 & 0.01 & $\mathbf{- 0 . 7 9}$ & $\mathbf{- 0 . 7 2}$ & 1.00 & -0.06 & -0.25 \\
\hline
\end{tabular}

Statistically significant values of correlation coefficient $\mathrm{p} \leq 0.05$ are bold $(\mathrm{N}=8)$

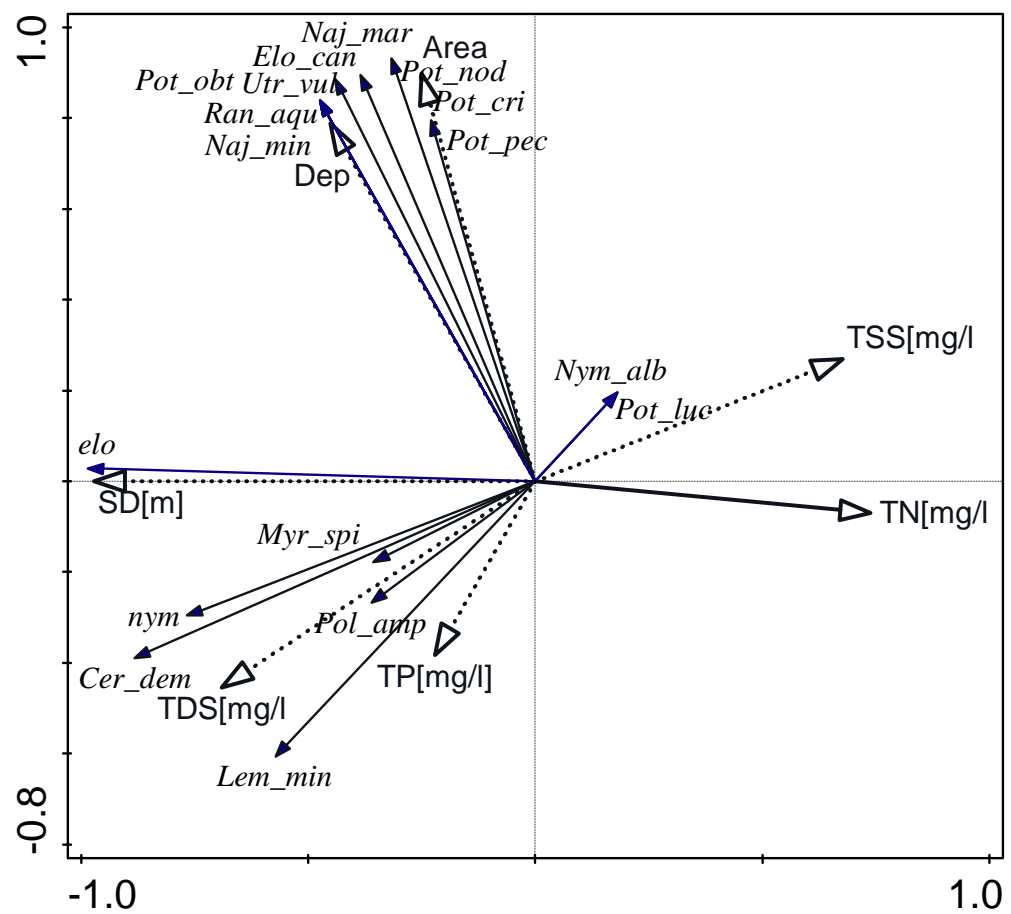

Figure 2. Results of the Principal Component Analysis (PCA) Diversity of aquatic vegetation (Species see Table 2, elo-elodeids, nym- nymphaeids) with relation to analyzed hydromorphological (Area - surface water area of reservoirs, Dep -depth of reservoirs) and physico-chemical parameters of water (SD - water transparency, TDS - salinity, TP - total phosphorus concentration, TN - total nitrogen concentration, TSS - total suspended solid concentration) 
Table 5. Values of the correlation coefficient between hydromorphological and physicochemical parameters of water and axes I and II of the PCA model

\begin{tabular}{c|c|c}
\hline Parameter & Axis I & Axis II \\
\hline SD $[\mathbf{m}]$ & -0.97 & 0.00 \\
TP $\left[\mathbf{m g} \cdot \mathbf{l}^{-1}\right]$ & -0.22 & -0.38 \\
TSS $\left[\mathbf{m g} \cdot \mathbf{l}^{-1}\right]$ & 0.68 & 0.27 \\
TN $\left[\mathbf{m g} \cdot \mathbf{l}^{-1}\right]$ & 0.74 & -0.07 \\
TDS $\left[\mathbf{m g} \cdot \mathbf{l}^{-1}\right]$ & -0.69 & -0.45 \\
Depht $[\mathbf{m}]$ & -0.45 & 0.79 \\
Area $[\mathbf{h a}]$ & -0.25 & 0.90 \\
\hline
\end{tabular}

In the RDA model, canonical axes significantly account for $94.22 \%$ of the variation. The first axis is positively correlated with average percentage cover of elodeids (ELO, 0.86 ) and nymphaeids (Nym 0.75) and accounts for 52.15\% of the variation of the main water quality parameters (SD, TN, TP, TSS). The statistical significance of the relation was confirmed by Monte Carlo test (test of first axis F value 2.7, p<0.05) (Figure 3).

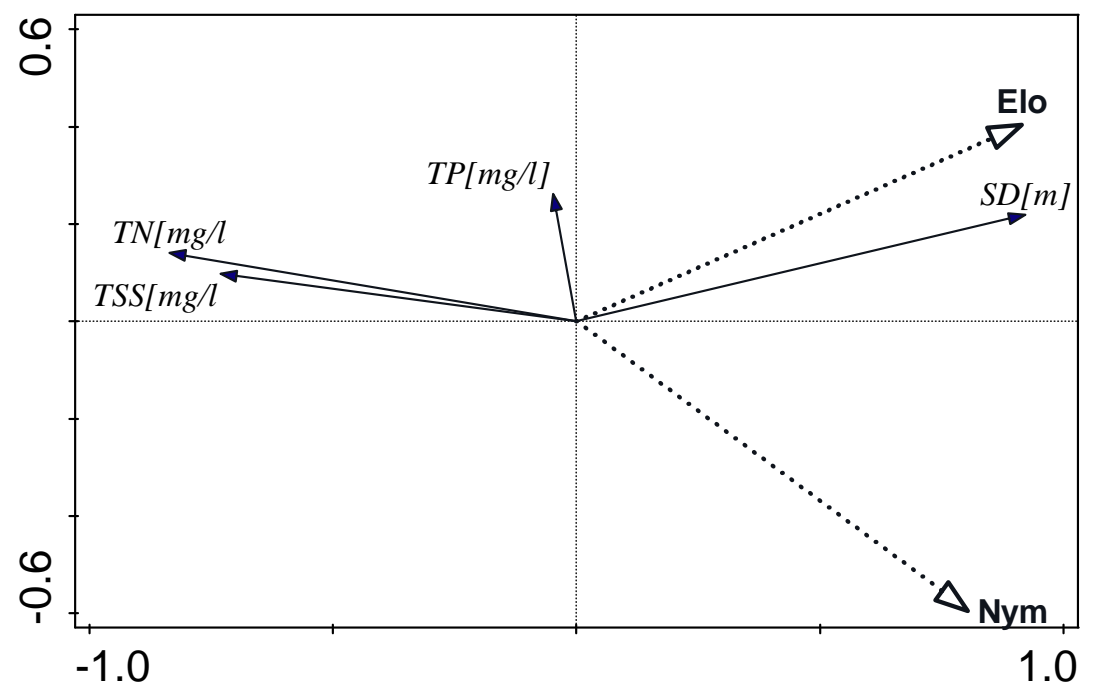

Figure 3. Results of Redundancy Analysis (RDA). Correlations between explanatory variable (Elo - average percentage coverage of elodeids, Nym - average percentage coverage of nymphaeids) and response variable (SD - water transparency, TP - total phosphorus concentration, TN - total nitrogen concentration, TSS - total suspended solid concentration)

\section{Discussion}

A persistent regime of transparent water is perceived as more desirable due to a greater utility value and the subsequent development of biological diversity of a fresh water reservoir (Moss, 1998; Scheffer et al., 2003; Cardinale, 2011) among water parameters. Multiple authors claim that water transparency in fresh water ecosystems greatly depends on low concentrations of phosphorus (Schindler, 1977; Kentzer, 2001; Suchowiec and Górniak, 2006; Vitense et al., 2019). Despite the fact that the concentration of phosphorus does not directly affect water transparency, low concentrations of this element may inhibit the development of phytoplankton. It has 
been proven within this paper that the concentration of phosphorus is not a key factor affecting the transparency of water in the analyzed reservoirs. Although there were significant differences in the transparency of water in the particular reservoirs, the concentration of phosphorus was at similar concentration in water in all of them.

Similar to phosphorus, for reservoirs with a turbid water regime (group II) there were no significant differences between the concentration of nitrogen when compared to reservoirs with a transparent water regime (group I). This indicates that the concentration of nitrogen is not important factor responsible for maintaining a regime with turbid water in the ecosystems of MSR.

The results of this study show that the depth and area of a reservoir are important factors that determine the species composition of submerged vegetation. However, these factors did not indicate significant correlation with water transparency (Table 5). The results of T-test also did not indicte significant differences between the two group of reservoirs (Table 4). As reservoir 2 are deeper than reservoirs 3, 4 and 5, it was assumed that it would have a higher level of water transpirancy. However results show, that a clarity of water is lower in Reservoir 2 (Table 1). This indicate that the depth is the one of many important factors which determines water quality in mining subsidence reservoirs.

Since reservoirs with a transparent water regime were characterized by elevated concentrations of dissolved compounds and a correlations between salinity and transparency were found, it appears that it is the elevated concentration of dissolved ions that may constitute a significant factor which is responsible for maintaining a transparent water regime in these ecosystems. Increased salinity (> $1000 \mathrm{mg} \mathrm{TDS} \mathrm{l}^{-1}$ ) may directly inhibit the development of phytoplankton (Raclavská et al., 2003; Redden and Rukminasari, 2008; Flöder et al., 2010; Belovsky et al., 2011). A concentration of dissolved solids exceeding $200 \mathrm{mg} \cdot \mathrm{l}^{-1}$ may lead to an increase in water transparency by reducing the concentration of undissolved solids (Oliver et al., 1999; Nielsen and Hillman, 2000). Calcium and magnesium ions, in particular, coagulate with other particles in a column of water, and leads to their sedimentation. Nevertheless, the Bartosuvka reservoir (Reservior 2) was characterized by one of the lowest SD values $(<1 \mathrm{~m})$ despite high concentrations of dissolved compounds $\left(542-790.00 \mathrm{mg} \mathrm{l}^{-1}\right)$. This indicates that increased salinity is not the solitary mechanism that impacts the improvement of water quality of mining subsidence reservoirs.

A regime with transparent water was maintained in all the reservoirs where the littoral zone was characterized by a significant average percentage covers usually much higher than $25 \%$ of aquatic vegetation. The percentage cover of submerged vegetation has a positive correlation with water transparency. This substantiates of results research Schefer (1998), Moss (1998, 2007) and Hejzlar (2006), that aquatic vegetation play an essential role as necessary element in maintaining a transparent water regime in freshwater ecosystems.

Tested reservoirs varied in their concentrations of both total phosphorus and nitrogen. The results appear to support the assumptions of the theory of alternative stable states, which claims that a transparent water regime may remain stable under a wide range of physico-chemical parameters since particular regimes remain constant as a result of complex bio-physico-chemical interactions that taking place in the ecosystem (Moss, 1998; Scheffer et al., 2003; Rameshkumar et al., 2019). Appropriate explanation of those interactions requires further detailed research, however, on the basis of the obtained results it may be assumed that the percentage cover of submerged vegetation is 
important factors responsible for maintaining a regime with transparent water in the ecosystems of mining subsidence reservoirs. The increased salinity of the water of such reservoirs does not limited the submerged vegetation from developing. TDS may cause susceptible species to retreat (Hart et al., 1991; Metzeling et al., 1995; Bailey, 1998; Bailey and James, 2000).

Presented results support the assumed hypothesis about the positive effect of submerged vegetation on the quality of water in subsidence reservoirs. Simultaneously this study show possibility the use of reclamation methods based on supporting the development of submerged vegetation in anthropogenic water reservoirs to increase the environmental and utility potential of such objects is validated by this research.

Results of presented research was obtained a few years ago, but did not lose their science value and are the complementary in the related field in investigation of the role submerged vegetation functioning in anthropogenic mining water reservoirs. Presented results are important in post-mining areas in the aspect of their revitalization of subsidence reservoirs while this issue is not wide recognized by other authors.

\section{Conclusions}

1. Submerged vegatation were proved to have the capability to increase the clarity of water in mining subsidence reservoirs.

2. If submerged vegetation cover quarter surface area of the MSR causes higher water transparency.

3. Therefore submerged plants is a good alternative in keeping a clear waterstate in mining subsidence reservoirs as in lakes.

4. Further work requires research of mining subsidence reservoirs of various sizes, controlled introduction of sumerged vegetation with different coverage, selection of species with different functional characteristics in situ and recognition of submerged and of floating plants relationships.

Acknowledgements. This work was supported by the Ministry of Science and Higher Education, Republic of Poland (Statutory Activity of the Central Mining Institute in Katowice, Poland. Work no. 11110417-342).

\section{REFERENCES}

[1] Bachmann, R. W., Horsburgh, C. A., Hoyer, M. V., Mataraza, L. K., Canfield, D. E. (2002): Relations between trophic state indicators and plant biomass in Florida lakes. Hydrobiologia 470: 219-34.

[2] Bailey, P. (1998): Effects of Increased Salinity on Riverine and Wetland Biota. - Project UM018. Final report, LWRRDC. Canberra.

[3] Bailey, P., James, K. (2000): Riverine and Wetland Salinity Impacts. - Assessment of R.D. Land and Water Australia. Report OP25/99. Australia.

[4] Belovsky, G. E., Stephens, D., Perschon, C., Birdsey, P., Paul, D., Naftz, D., Baskin, R., Larson, C., Mellison, C., Luft, J., Mosley, R., Mahon, H., Van Leeuwen, J., Allen, D. V. (2011): The Great Salt Lake Ecosystem (Utah, USA): long term data and a structural equation approach. - Ecosphere 2: 1-40.

[5] Canoco for Windows Version 4.1. - Biometris-Plant Research International, Wageningen, The Netherlands. 
[6] Cardinale, B. J. (2011): Biodiversity improves water quality through niche partitioning. Nature 472: 86-89.

[7] Coops, H., Doef, R. W. (1996): Submerged vegetation development in two shallow, eutrophic lakes. - Hydrobiologia 340: 115-120.

[8] Flöder, S., Jaschinski, S., Wells, G., Burns, C. W. (2010): Dominance and compensatory growth in phytoplankton communities under salinity stress. - Journal of Experimental Marine Biology and Ecology 395(1-2): 223-231.

[9] Gross, E. M., Sütfeld, R. (1994): Polyphenols with algicidal activity in the submerged macrophyte Myriophyllum spicatum L. - Acta Hortic 381: 710-16.

[10] Grulich, V., Vydrová, A. (2006): Methodology of sampling and processing of macrophytes of still waters [Metodika odberu a zpracování vzorku makrofyt stojatých vod]. - Masaryk Water Research Institute.

[11] Hart, B. T., Bailey, P., Edwards, R., Hortle, K., James, K., McMahon, A., Meredith, C., Swadling, K. (1991): A review of the salt sensitivity of the Australian freshwater biota. Hydrobiologia 210: 105-144.

[12] Hasler, A. D., Jones, E. (1949): Demonstration of the antagonistic action of large aquatic plants on algae and rotifers. - Ecology 30: 346-59.

[13] Hejzlar, J. (2006): The EU framework directive for water policy and water quality in reservoirs. [Rámcová směrnice vodní politiky EU a kvalita vody v nádržích]. - Vodní hospodářství 56: 190-196.

[14] Hilt, S., Gross, E. M., Hupfer, M., Morscheid, H., Mählmann, J., Melzer, A., Van de Weyer, K. (2006): Restoration of submerged vegetation in shallow eutrophic lakes-a guideline and state of the art in Germany. - Limnologica-Ecology and Management of Inland Waters 36(3): 155-171.

[15] Irfanullah, H. M., Moss, B. (2004): Factors influencing the return of submerged plants to a clear-water, shallow temperate lake. - Aquatic Botany 80(3): 177-191.

[16] Jeppesen, E., Jensen, J. P., Kristensen, P., Søndergaard, M., Mortensen, E., Sortkjær, O., Olrik, K. (1990): Fish manipulation as a lake restoration tool in shallow, eutrophic, temperate lakes 2: threshold levels, long-term stability and conclusions. - Hydrobiologia 200-201: 219-28.

[17] Kašovská, K., Pierzchała, Ł., Sierka, E., Stalmachová, B. (2014): Impact of The Salinity Gradient on The Mollusc Fauna In Flooded Mine Subsidences (Karvina, Czech Republic). - Archives of Enviromental Protection 40(1): 87-101.

[18] Kentzer, A. (2001): Phosphorus and its biologically available fractions in lake sediments of various trophies. [Fosfor i jego biologicznie dostępne frakcje w osadach jezior różnej trofii]. - Wydawnictwo UMK. Hydrobiologia. Torun.

[19] Kosten, S., Gissell Lacerot, G., Jeppesen, E., da Motta Marques, D., van Nes, E. H., Mazzeo, N., Scheffer, M. (2009): Effects of submerged vegetation on water clarity across climates. - Ecosystems 12: 1117-1129.

[20] Lepš, J., Šmilauer, P. (2000): Multivariate analysis of ecological data [Mnohorozmerrná analýza ekologických dat.]. - Biologická fakulta Jihočeské univerzity v Českých Budějovicích, České Budějovice, 102p.

[21] Li, K., He, W., Hu, Q., Gao, S. (2014): Ecological restoration of reclaimed wastewater lakes using submerged plants and zooplankton. - Water and Environment Journal 28: 323-328.

[22] Macoun, J., Šibrava, V., Tyra, J., Kneblova-Vodikova, V. (1965): Outer Subcarpathia of Moravian Gate [Kvarter Ostravska a Moravske brany]. - Ústav. Geol. Praha.

[23] Menčik, E. (1983): Geology of the Moravian-Silesian Beskids and Podbeskydská Hills [Geologie Moravskoslezkých Beskyd a Podbeskydské pahorkatny]. - ÚÚG.

[24] Metzeling, L., Doeg, T., O'Connor, W. (1995): The impact of salinisation and sedimentation on aquatic biota. - Conserving Biodiversity: Threats and Solutions: 126136. 
[25] Molenda, T., Rzętała, M. A. (2001): The role of natural and anthropogenic factors in the formation of coastal zones of artificial water reservoirs [Rola naturalnych i antropogenicznych czynników w kształtowaniu się stref brzegowych sztucznych zbiorników wodnych]. - Wydział Nauk o Ziemi 29(4): 52-55.

[26] Moss, B. (1998): Shallow Lakes Biomanipulation and Eutrophication. - Scope Newsletter 29: 2-45.

[27] Moss, B. (2007): Art and science of lake restoration. - Hydrobiologia 581: 15-24.

[28] Nakamura, K., Kayaba, Y., Nishihiro, J., Takamura, N. (2008): Effects of submerged plants on water quality and biota in large-scale experimental ponds. - Landscape Ecol Eng 4: 1-9.

[29] Nielsen, D. L., Hillman, T. J. (2000): The status of research into the effects of dryland salinity on aquatic ecosystems. - A discussion paper arising from a salinity workshop in Albury, NSW, on 13th December 1999. CRCFE technical report.

[30] Oliver, R. L., Hart, B. T., Olley, J., Grace, M., Rees, C., Caitcheon, G. (1999): The Darling River: Algal Growth and the Cycling and Sources of Nutrients. - Final report to the Murray-Darling Basin Commission.

[31] Pertile, E. (2007): Hydrochemistry of watered subsidence area of Karviná [Hydrochemie zvodnělých poklesových kotlin ve vymezeném území Karvinska]. - Vysoká škola báňská - Technická univerzita Ostrava. Hornicko-geologická fakulta. Ostrava, Czech Republic.

[32] Phillips, G., Willby, N., Moss, B. (2016): Submerged macrophyte decline in shallow lakes: What have we learnt in the last forty years? - Aquatic Botany 135: 37-45.

[33] Pierzchała, Ł., Sierka, E., Trząski, L., Bondaruk, J., Czuber, B. (2016): Evaluation of the suitability of anthropogenic reservoirs in urban space for ecological restoration using submerged plants (Upper Silesia, Poland). - Applied Ecology and Environmental Research 14(1): 277-296.

[34] Plaček, V. (1984): Okres Karviná. [District Karviná]. - Ostrava: Profil.

[35] Raclavská, H., Matýsek, D., Pertile, E., Šajer, J., Soldán, P., Sviták, J. (2003): Initiation of natural ecosystems in mining impected area for revitalization of Karvina district [Iniciace prírodních ekosystémů poddolované krajiny pro proces obnovy území]. Karvinska, MŽP VaV/640/1/01. MS VŠB-TU. 2001 - 2003. Ostrava. Czech Republic.

[36] Rameshkumar, S., Radhakrishnar, K., Aanand, S., Rajaram, R. (2019): Infuence of physicochemical water quality on aquatic macrophyte diversity in seasonal wetlands. Applied Water Science 9: 12. https://doi.org/10.1007/s13201-018-0888-2.

[37] Redden, A. M., Rukminasari, N. (2008): Effects of increases in salinity on phytoplankton in the Broadwater of the Myall Lakes, NSW, Australia. - Hydrobiologia 608: 87. https://doi.org/10.1007/s10750-008-9376-2.

[38] Schaumburg, J., Schranz, C., Hofmann, G., Stelzer, D., Schneider, S., Schmedtje, U. (2004): Macrophytes and phytobenthos as indicators of ecological status in German lakes - a contribution to the implementation of the Water Framework Directive. - Limnologica 34(4): 302-314.

[39] Scheffer, M., Hosper, S. H., Mijer, M-L., Moss, B., Jeppesen, E. (1993): Alternative equilibria in shallow lakes. - Trends in Ecology \& Evolution 8(8): 275-279.

[40] Scheffer, M. Ch. H. (1998): Ecology of Shallow Lakes. - London.

[41] Scheffer, M., Szabo, S., Gragnani, A., van Nes, E. H., Rinaldi, S., Kautsky, N., Norberg, J., Roijackers, R. M. M., Franken, R. J. M. (2003): Floating plant dominance as a stable state. - Proceedings of the National Academy of Science of the United States of America 100: 4040-4045.

[42] Schindler, D. W. (1977): Evolution of Phosphorus Limitation in Lakes. - Science 21(195): 260-262.

[43] Sierka, E., Stalmachova, B., Molenda, T., Pierzchała, Ł. (2012): Environmental and social - economic importance of subsidence reservoirs. - ISBN 978-80-7300-445-3. Praha. Czech Republic. 
[44] Šmilauer, P., Lepš, J. (2014): Multivariate analysis of ecological data using CANOCO 5. - Cambridge University Press; Cambridge.

[45] Stalmachová, B. (2003): Recovery strategy of mining landscape [Strategie obnovy hornické krajiny]. - Technická univerzita Ostrava, Hornicko-geologická fakulta. Ostrava.

[46] Statistica ver. 12.0. - StatSoft, Inc. USA.

[47] Strzelec, M., Spyra, A., Serafiński, W. (2010): Biology of inland waters [Biologia wód środlądowych]. - Wydawnictwo Uniwersytetu Śląskiego. Katowice.

[48] Suchowiec, T. A., Górniak, A. (2006): Seasonality of water quality of small retention reservoirs in the agricultural landscape of Podlasie region [Sezonowość jakości wody małych zbiorników retencyjnych w krajobrazie rolniczym Podlasia]. - Woda Środowisko Obszary wiejskie 2(18): 347-359.

[49] Tokarska-Guzik, B., Rostański, A. (1996): The role of post-mining floods (floodplains) in the renaturalization of the industrial landscape of Upper Silesia [Rola zatopisk (zalewisk) pogórniczych w renaturalizacji przemysłowego krajobrazu Górnego Śląska.]. - Przegląd Przyrodniczy 7(3): 267-272.

[50] Verhofstad, M. J. J. M., Alirangues Núñez, M. M., Reichman, E. P., van Donk, E., Lamers, L. P. M., Bakker, E. S. (2017): Mass development of monospecific submerged macrophyte vegetation after the restoration of shallow lakes: roles of light, sediment nutrient levels, and propagule density. - Aquat. Bot. 141: 29-38.

[51] Vitense, K., Hanson, M. A., Herwig, B. R., Zimmer, K. D., Fieberg, J. (2019): Predicting total phosphorus levels as indicators for shallow lake management. - Ecological indicators 96: 278-287.

[52] Wang, L., Han, Y., Yu, H., Fan, S., Liu, Ch. (2019): Submerged Vegetation and Water Quality Degeneration From Serious Flooding in Liangzi Lake, China. - Front Plant Sci. 10: 1504.

[53] Woźniak, G., Sierka, E., Wheeler, A. (2018): Urban and industrial habitats: how important they are for ecosystem services. - Ecosystem Services and Global Ecology. 